\title{
Sorbitol- and Other Sugar-induced Expressions of the NAD+-dependent Sorbitol Dehydrogenase Gene in Japanese Pear Fruit
}

\author{
Motoko Iida, Nancy A. Bantog1, Kunio Yamada, Katsuhiro Shiratake, and Shohei Yamaki² \\ Graduate School of Bioagricultural Sciences, Nagoya University, Chikusa, Nagoya 464-8601, Japan
}

\begin{abstract}
ADDITIONAL INDEX WORDS. NAD-SDH antibody, NAD-SDH cDNA, Pyrus serotina, sugar accumulation
ABSTRACT. The regulation of $\mathrm{NAD}^{+}$-dependent sorbitol dehydrogenase (NAD-SDH, EC 1.1.1.14) by sugar was investigated by using sliced tissues of japanese pear (Pyrus serotina Nakai cv. Kousui) fruit in order to determine its role in the mechanism of sugar accumulation in fruit tissue. The results of the activities and steady-state levels of the protein and mRNA indicate that NAD-SDH in japanese pear fruit is among the sugar-inducible genes. By preincubating the sliced tissues for 16 hours in a medium without sugar, NAD-SDH activity declined and reached a stable level that was maintained for up to $\mathbf{4 0}$ hours. The washing procedure also reduced the sugar concentration in the apoplast and cytosol of the sliced tissues to low concentrations and enabled them to be manipulated by exogenous applications of carbohydrate solutions. Incubation of tissues in 50 or $100 \mathrm{~mm}$ sorbitol for 8 hours led to enhanced expression of the NAD-SDH gene as determined by increased mRNA and protein levels and enhanced enzyme activity. The presence of $100 \mathrm{~mm}$ glucose, sucrose, or mannitol also gave significant stimulation on the levels of activity, protein, and mRNA of NAD-SDH compared with those of control tissues bathed in media in which the osmotic potential had been adjusted to that of the sugar solutions by adding polyethylene glycol. However, fructose was ineffective in stimulating NAD-SDH activities and the level of the protein was not enhanced but the level of mRNA was increased. Therefore, it is suggested that NAD-SDH gene transcription is enhanced by each sugar investigated, and fructose appears to be unique as it also influences NAD-SDH at a post-transcriptional level.
\end{abstract}

One of the main processes governing plant growth and development is the regulation of assimilate accumulation and partitioning that is mainly determined by sink strength (Gifford and Evans, 1981). Sink strength is the ability of the sink organ to competitively attract assimilates (Ho, 1988). Whereas acid invertase and sucrose synthase are important in maintaining the sink strength in sucrose-translocating plants, NAD+-dependent sorbitol dehydrogenase (NAD-SDH, EC 1.1.1.14) has been ascribed a key role in the regulation of sink activity in sorbitol-translocating plants (Loescher et al., 1982; Yamaki and Ishikawa, 1986). NAD-SDH has been purified and characterized from japanese pear fruit, and comprises four subunits of the 40-kDa polypeptide (Oura et al., 2000). Its cDNA clones have been isolated from the fruits of apple (Malus pumila Mill. var. domestica Schneid.) (Yamada et al., 1998), peach (Prunus persica L.) (Yamada et al., 2001), and loquat (Eriobotrya japonica Lindl.) (Bantog et al., 2000). Four isogenes of NAD-SDH are in apple (Park et al., 2002).

Sugars modulate gene expression in plants (Koch, 1996). Particularly evident is stimulation in activities of enzymes participating in sugar metabolism in sink organs. The acid invertase gene is up-regulated in Chenopodium rubrum L. (Roitsch et al., 1995). Enzyme activation and gene induction of sucrose synthase have been reported for eggplant fruit (Solanum melongena L.) (Lee et al., 1997) and leaves (Claussen et al., 1986), potato (Solanum tuberosum L.) leaves and petioles (Salanoubat and Belliard, 1989), potato tuber (Fu et al., 1995), maize (Zea mays L.) (Koch et al., 1992), and Chenopodium rubrum (Godt et al., 1995). Sucrosephosphate synthase induction is at the gene level in the sugar

Received for publication 5 Aug. 2003. Accepted for publication 25 June 2004 This research was supported in part by a grants-in-aid (No. 09306002) from the Ministry of Education, Science, Sports and Culture of Japan.

${ }^{1}$ Present address: Dept. of Science and Technology, Cordillera Administrative Region, Km. 6, La Trinidad, Benguet 2601, Philippines.

${ }^{2}$ To whom reprint requests should be addressed. beet (Beta vulgaris L.) petiole (Hesse et al., 1995). However, in sucrose synthase and invertase, some isozymes are present that are regulated independently by different sugars (Fu et al., 1995; Roitsch et al., 1995). That is, some isozymes are up-regulated and some isozymes are down-regulated by each sugar.

In a suspension culture of the callus of celery (Apium graveolens L.), mRNA expression of mannitol dehydrogenase, which converts mannitol to fructose, is repressed by glucose, and is derepressed once glucose in the media has been consumed, the so-called famine condition (Prata et al., 1997). In the presence of hexose, mannitol dehydrogenase expression is transcriptionally repressed with the result that hexoses are preferentially consumed and mannitol pools are conserved. NAD-SDH activity in apple fruit was found to be enhanced by sorbitol and glucose but not by fructose (Archbold, 1999). Furthermore, reduced supply of sorbitol in girdled apple fruit led to decreased NAD-SDH activity (Berüter and Feusi, 1997). The expression of NAD-SDH may be regulated at the gene level by sorbitol and other sugars. Therefore, in this study, we investigated how sugars influence the expression of NAD-SDH at the gene level by using the sliced tissue of immature japanese pear fruit.

\section{Materials and Methods}

MAterials AND SAMPle PREPARATion. Fruit of japanese pear ('Kousui') were harvested from Nagoya Univ. (Nagoya, Japan) orchard on 6 July 2001, at which stage the fruit were $\approx 45 \mathrm{~g}$ fresh weight and were just starting expansion growth. After harvesting, the fruit were kept at $4^{\circ} \mathrm{C}$ for several days. The fruit were peeled and were cut lengthwise into four pieces, and the hard cores were removed. Both blunt and narrow ends of the pieces were removed. Sliced tissues of $5 \mathrm{~mm}$ thickness were prepared and were put into a washing medium composed of $10 \mathrm{~mm}$ MES-KOH buffer $(\mathrm{pH}$ 6.5) containing $10 \mathrm{~mm} \mathrm{Na-ascorbate.}$ 
INCUBATION OF SLICED TISSUE. Sliced tissues (20 g) were incubated twice in medium A (10 mm MES-KOH buffer ( $\mathrm{pH}$ 6.5), 2 $\mathrm{mm}$ dithiothreitol, $2 \mathrm{~mm} \mathrm{CaCl}_{2}$ ) for 3 min to wash them. For the sugar-releasing experiment, the sliced tissues were incubated for 40 $\mathrm{h}$ at $25^{\circ} \mathrm{C}$ in medium $\mathrm{A}$, which was exchanged after 1, 6, 16, 24, and $32 \mathrm{~h}$. At each time, sugars contained in the incubation media were assayed. For experiments investigating the effects of sugar on NAD-SDH expression, the sliced tissues were preincubated for $16 \mathrm{~h}$ at $25^{\circ} \mathrm{C}$ as described above. Then $100 \mathrm{~mm}$ sorbitol, glucose, fructose, sucrose, or mannitol, or $10 \%$ polyethylene glycol 8000 (PEG) was supplied in media A to keep the osmotic potential equal to $100 \mathrm{~mm}$ sugar in medium A, as described by Archbold (1999). The sliced tissues were incubated for $24 \mathrm{~h}$ with the media exchanged every $8 \mathrm{~h}$. After incubation, the sliced tissues were washed once with distilled water, frozen in liquid nitrogen, and stored at $-80^{\circ} \mathrm{C}$ until used for assay.

TOTAL RNA EXTRACTION AND AMPLIFICATION OF JAPANESE PEAR NAD-SDH CDNA FRAGMENT. Total RNA was extracted from $10 \mathrm{~g}$ frozen sliced tissues by using the phenol-sodium dodecyl sulfate (SDS) method (Nakajima et al., 1988) combined with the cetyltrimethylammonium bromide method (Murray and Thompson, 1980). An NAD-SDH cDNA fragment of japanese pear fruit was amplified by RT-PCR as follows. From the total RNA, the first strand cDNA was synthesized using oligo-adaptor primer as recommended by the TaKaRa RNA PCR Kit (AMV) ver. 2.1 (Takara Bio. Inc., Shiga, Japan). Two oligonucleotide primers (sense primers: A:5'-GTTGGCATATGTGGCAGTGATGTT-3'; antisense primers: C:5'-GCGGCAGTTTCAGAGGTG-3') were designed from the apple NAD-SDH cDNA sequence (AC No. AB016256; Yamada et al., 1998). PCR was done with primers A and $\mathrm{C}$ and using the first strand cDNA as a template. An amplified fragment $[\approx 840$ base pairs (bp)] was cloned into the pT7BlueT vector (Novagen, Madison, Wisc.) by using the TAcloning method (Ichihara and Kurosawa, 1993) and was sequenced by using an ABI PRISM Big Dye Terminator Cycle Sequencing Ready Reaction Kit (Perkin-Elmer, Foster City, Calif.) with an automatic DNA sequencer (model 373; Perkin-Elmer). The deduced amino acid sequence of japanese pear NAD-SDH cDNA fragment showed an approximately $90 \%, 90 \%, 65 \%, 65 \%, 32 \%, 25 \%$, and $23 \%$ identity to that of apple, loquat, arabidopsis, peach, silk moth, human, and yeast NAD-SDH, respectively (data not shown). This plasmid DNA was used as a template in a PCR that with sense primer B:5'-TGGTCGTGGGAGCAGGACCTATATG-3' and antisense primers $C$ to create an amplified fragment $(\approx 440$ bp) as a probe.

ENZYME EXTRACTION AND ASSAY. The enzyme was extracted by using a modified Lo Bianco et al. (1998) method. Sliced tissues $(10 \mathrm{~g})$ were homogenized in $10 \mathrm{~mL}$ of $0.2 \mathrm{M}$ Tris-HCl buffer $(\mathrm{pH}$ 9.0) containing $2 \mathrm{~mm} 2$-mercaptoethanol, $8 \%(\mathrm{v} / \mathrm{v})$ glycerol, and $1 \%(\mathrm{w} / \mathrm{v})$ polyvinylpolypyrolidone. The homogenate was centrifuged at $10,000 g_{\mathrm{n}}$ for $20 \mathrm{~min}$. The supernatant was collected, its $\mathrm{pH}$ was adjusted to 9.5 , and it was passed over a Sephadex G-25 column $(1.3 \mathrm{~cm} \mathrm{D} \times 2.6 \mathrm{~cm}$; Amersham Pharmacia Biotech Co., Uppsala, Sweden). The eluate was used as the crude enzyme and soluble protein solution. NAD-SDH activity was assayed by measuring reduced NAD at $340 \mathrm{~nm}$ by using the method of Yamaki and Ishikawa (1986).

Protein determination. The amount of protein in the crude enzyme preparation was measured by using the method of Bensadoun and Weinstein (1976) with bovine serum albumin as a standard.
SDS-PAGE AND IMMUNOBLOTTING. SDS-PAGE was done as described by Laemmli (1970) in $12.5 \%$ (w/v) acrylamide gels. Immunoblotting was done by using the method of Towbin et al. (1979). The polyclonal antibody used for immunoblotting was raised in rabbit against NAD-SDH expressed in E. colitransformed with apple NAD-SDH cDNA (Yamada et al., 1999). Binding of antibodies was detected by a colorimetric reaction with alkaline phosphatase-conjugated goat anti-rabbit secondary antibodies.

RNA BLOT ANALYSIS. Total RNA $(20 \mu \mathrm{g})$ was electrophoresed on $1.0 \%$ agarose gels in the presence of $0.66 \mathrm{~m}$ formaldehyde and transferred to Hybond-N+ membrane (Amersham Pharmacia Biotech Co., Little Chalfont, England). The membrane was hybridized to ${ }^{32} \mathrm{P}-$ labeled japanese pear NAD-SDH cDNA fragment amplified by RT-PCR as described above. Hybridization was carried out in 6xSSPE ( 1 xSSPE; $150 \mathrm{~mm} \mathrm{NaCl}, 10 \mathrm{~mm}$ $\mathrm{NaH}_{2} \mathrm{PO}_{4}, 1$ mm ethylenediaminetetraacetate, $\left.\mathrm{pH} 7.4\right), 50 \%(\mathrm{v} / \mathrm{v})$ formamide, $5 \%(\mathrm{v} / \mathrm{v})$ Irish cream liquer (R. and A. Bailey \& Co., Dublin, Ireland), $0.5 \%(\mathrm{w} / \mathrm{v}) \mathrm{SDS}$, and $20 \mu \mathrm{g} \cdot \mathrm{mL}^{-1}$ denatured salmon sperm DNA at $45^{\circ} \mathrm{C}$ for $20 \mathrm{~h}$. The membrane was washed twice with $2 x S S P E / 0.1 \%$ (w/v) SDS at $65^{\circ} \mathrm{C}$ for $20 \mathrm{~min}$, twice. The results of hybridization were analyzed by using an imaging analyzer (BAS2000; Fuji Film Co., Tokyo).

SugarassaY. To measure the amounts of each sugar, aliquots of the incubation media were filtered $(0.45 \mu \mathrm{m}$; Adavantec, Tokyo) before injection on to a HPLC system (655A-11LC; Hitachi, Tokyo) fitted with a Sugar SP0810 column (Showa Denko Co., Tokyo). The analysis was done at a flow rate of $0.8 \mathrm{~mL} \cdot \mathrm{min}^{-1}$ of distilled water at $80{ }^{\circ} \mathrm{C}$ with a refractive index detector. The amount of each sugar was calculated from standard curves of authentic sugars.

\section{Results}

REMOVAL OF SUGARS FROM SLICED TISSUE DURING THE INCUBATION. To determine correctly the effect of each sugar added to the incubation media, the concentrations of sugars in the apoplast and cytosol of sliced tissues have to be kept at low levels. Therefore, the sliced tissues were incubated in media without sugars. During the first 1-h incubation, sugars were released from the tissues, and the total sugar concentration in the media was $17 \mathrm{~mm}$. During the next 5-h incubation from 1 to $6 \mathrm{~h}$ and the subsequent $10-\mathrm{h}$ incubation from 6 to $16 \mathrm{~h}$, the amount of sugar released each hour fell. After $16 \mathrm{~h}$ incubation, only a little sugar was released and the sugar concentration in the media collected during each 8 -h incubation from 16 to $24 \mathrm{~h}$, from 24 to $32 \mathrm{~h}$, and from 32 to 40 $\mathrm{h}$ was below $2 \mathrm{~mm}$ (Table 1). Therefore, for subsequent experiments, the sliced tissues were preincubated for $16 \mathrm{~h}$ in media without sugar, then were incubated for the different periods in media containing various sugars. The media containing the sugars was exchanged every $8 \mathrm{~h}$.

Table 1. Concentration of each sugar released into medium A during incubation of sliced tissues. The medium was renewed after 1, 6, 16, 24 , and $32 \mathrm{~h}$ incubation. Each value is the mean of two independent experiments. tr: means $<1 \mathrm{~mm}$.

\begin{tabular}{lcccccc}
\hline Sugar $(\mathrm{mm})$ & $0-1 \mathrm{~h}$ & $1-6 \mathrm{~h}$ & $6-16 \mathrm{~h}$ & $16-24 \mathrm{~h}$ & $24-32 \mathrm{~h}$ & $32-40 \mathrm{~h}$ \\
\hline Sorbitol & 5.9 & 9.4 & 8.7 & 1.4 & $\operatorname{tr}$ & $\operatorname{tr}$ \\
Fructose & 8.4 & 13.8 & 12.9 & 1.9 & $\operatorname{tr}$ & $\operatorname{tr}$ \\
Glucose & 2.2 & 3.2 & 3.5 & $\operatorname{tr}$ & $\operatorname{tr}$ & $\operatorname{tr}$ \\
Sucrose & $\operatorname{tr}$ & $\mathrm{tr}$ & $\mathrm{tr}$ & $\mathrm{tr}$ & $\mathrm{tr}$ & $\mathrm{tr}$ \\
\hline
\end{tabular}


Stabilization of NAD-SDH activity In SLICEd tissue. To mitigate the fluctuation of NAD-SDH activity caused by artificial stress during the preparation of sliced tissues, the slices were incubated without sugar in the same medum as for the sugar removed experiment. After $6 \mathrm{~h}$ incubation, NAD-SDH activity was reduced to $60 \%$ of the control ( $0 \mathrm{~h}$ incubation) (Fig. 1). Thereafter, the activity remained almost constant during the incubation period from 6 to $40 \mathrm{~h}$. Thus, we decided that a $16 \mathrm{~h}$ preincubation with renewal of media at 1 and $6 \mathrm{~h}$ was enough to get the stable activity and to avoid the influence of released sugars in the media.

EFFECT OF SORBITOL CONCENTRATION ON THE EXPRESSION OF NAD-SDH. Sorbitol at 50, 100, or $200 \mathrm{~mm}$ was added to the medium after $16 \mathrm{~h}$ preincubation of sliced tissues (Fig.2a). Then, the tissues were incubated for $24 \mathrm{~h}$ with media renewal every 8 h. The NAD-SDH activity increased 1.5, 1.4, and 1.6 times the control activity ( $0 \mathrm{~mm}$ sorbitol) at 50,100, and $200 \mathrm{~mm}$ sorbitol, respectively. Immunoblotting after SDS-PAGE showed two reactive bands at $\approx 40 \mathrm{kDa}$, which we considered to be caused by the NAD-SDH protein. NAD-SDH protein bands also increased at each sorbitol concentration (Fig. 2b). The steady-state level of NAD-SDH mRNA estimated by northern blot analysis increased to $1.5,2.1$, and 1.9 times the control at 50,100, and $200 \mathrm{~mm}$ sorbitol, respectively (Fig. 2c) together with the increase in the activity and protein of NAD-SDH.

TIME COURSE ANALYSIS ON THE EXPRESSION OF NAD-SDH WITH SORBITOL. The NAD-SDH activity increased slightly after $8 \mathrm{~h}$ incubation of sliced tissues in $100 \mathrm{~mm}$ sorbitol and increased more after 16 and $24 \mathrm{~h}$ incubation (Fig. 3a), but incubation without sorbitol did not enhance the activity, which remained constant for $24 \mathrm{~h}$ after preincubation (Fig. 1). That is, the induction of activity started after $8 \mathrm{~h}$ incubation. The amount of NAD-SDH protein estimated by immunoblot analysis increased 1.8 times at $8 \mathrm{~h}$ incubation (Fig. 3b). The transcript increased before the increase in activity, and was $1.3,1.5$, and 1.4 times the control after incubation for 8, 16, and $24 \mathrm{~h}$, respectively (Fig. 3c).

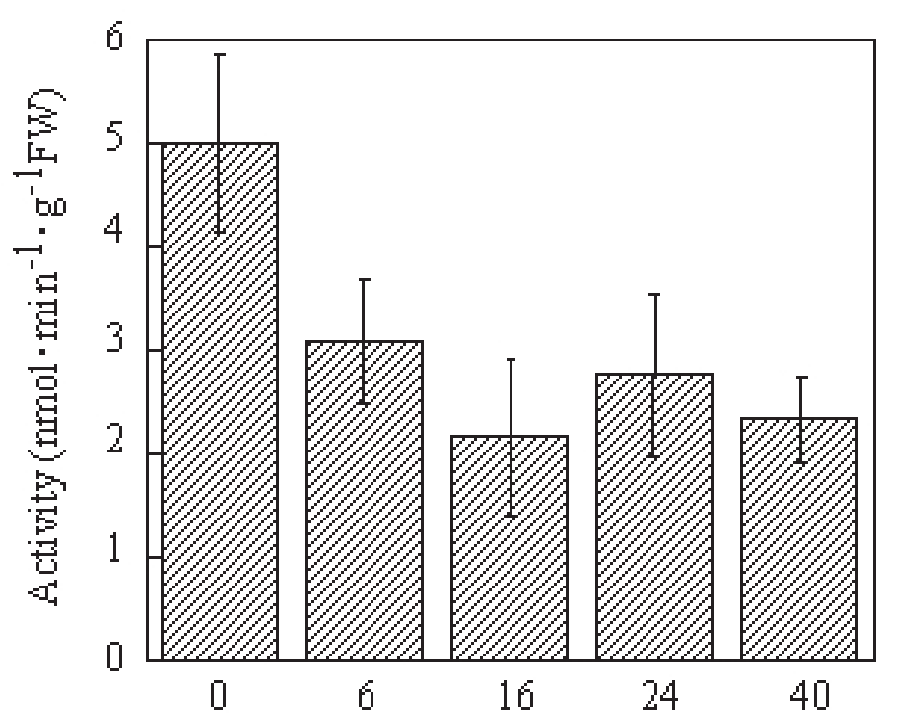

Incubation time (h)

Fig. 1. Time course of NAD-SDH activity in sliced tissues incubated in a medium without sugars. Sliced tissues were incubated in medium A for $0,6,16,24$, and $40 \mathrm{~h}$ at $25^{\circ} \mathrm{C}$. Medium A was renewed at each of these times. Each value is the mean \pm SE of three independent experiments. $\mathrm{FW}=$ fresh weight.

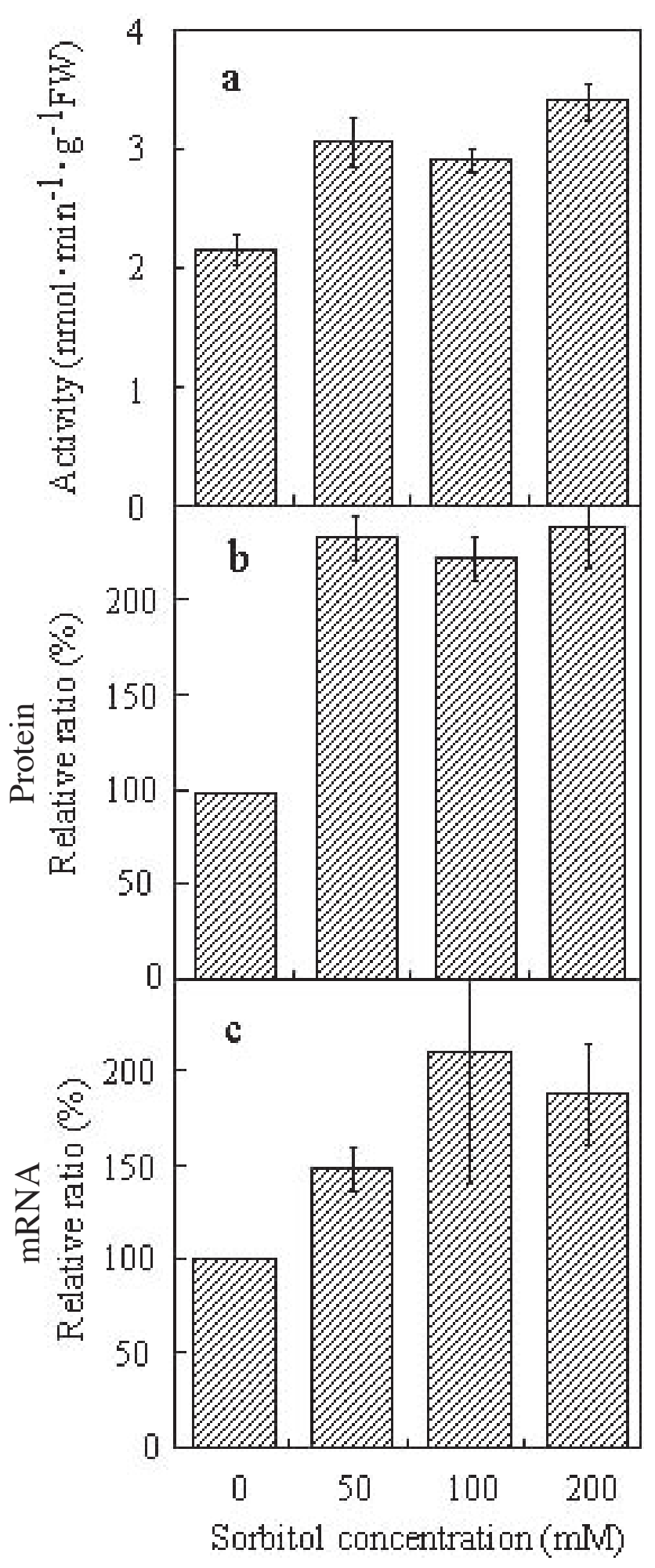

Fig. 2. Effect of sorbitol concentration to enhancement of activity, protein, and mRNA levels of NAD-SDH. Sliced tisuues were incubated in medium A with $0,50,100$, and $200 \mathrm{~mm}$ sorbtiol for $24 \mathrm{~h}$ at $25^{\circ} \mathrm{C}$ after $16 \mathrm{~h}$ preincubation. (a) Activity: extraction and assay for NAD-SDH activity was described in the materials and methods. (b) Protein: soluble protein $(20 \mu \mathrm{g})$ in the enzyme extract was separated by SDS-PAGE. For immuno detection, rabbit antibody raised against apple NAD-SDH was used. The relative ratio to the control $(0$ mm sorbitol) was shown. (c) mRNA: total RNA (20 $\mu \mathrm{g} /$ lane) isolated from sliced tissues was hybridized with the radio-labeled partial NAD-SDH cDNA probe from japanese pear fruit. The relative ratio to the control ( $0 \mathrm{~mm}$ sorbitol) is shown. Each value of $\mathbf{a}, \mathbf{b}$, and $\mathbf{c}$ is the mean \pm SE of three independent experiments. $\mathrm{FW}=$ fresh weight. 


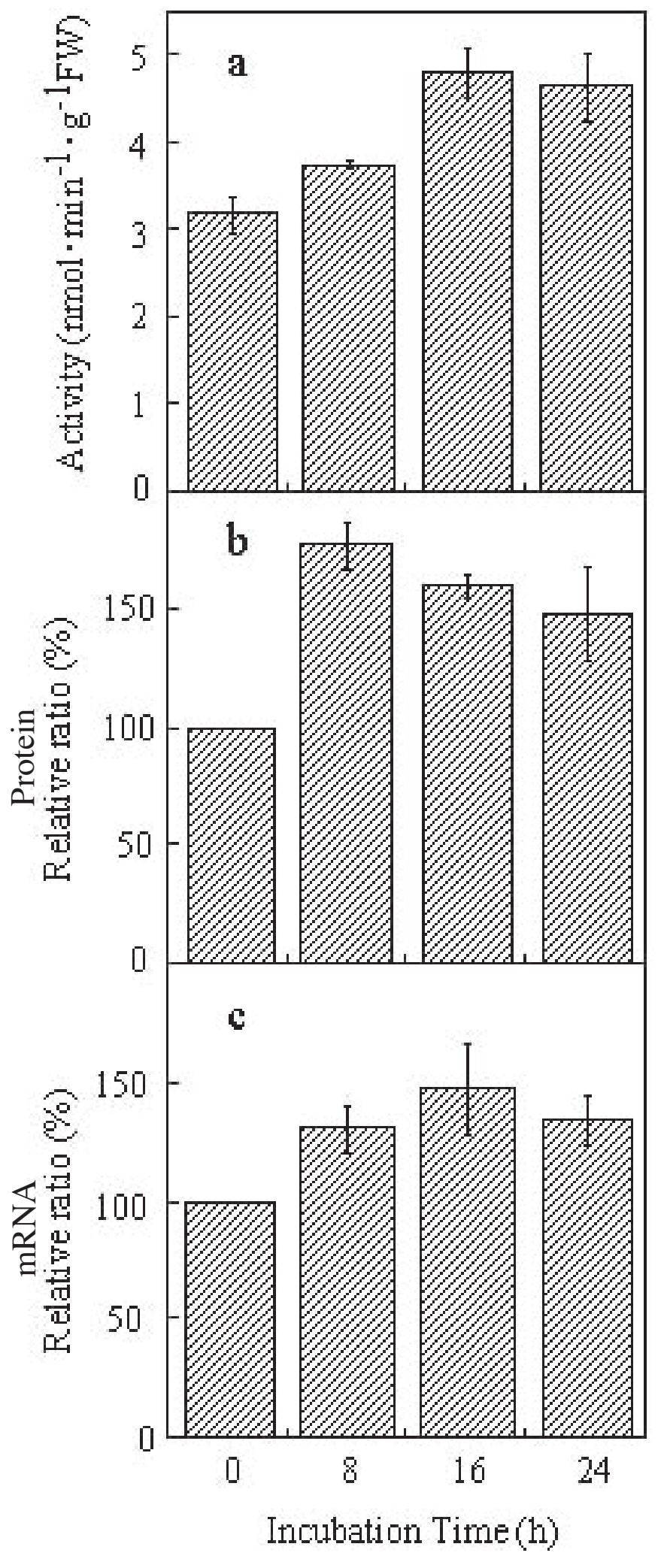

Fig. 3. Time course analysis to enhancement of activity, protein and mRNA levels of NAD-SDH. Sliced tissues were incubated in medium A with $100 \mathrm{~mm}$ sorbtiol for $0,8,16$, and $24 \mathrm{~h}$ at $25^{\circ} \mathrm{C}$ after $16 \mathrm{~h}$ preincubation. (a) NAD-SDH activity. (b) The relative ratio of NAD-SDH protein to the control ( $0 \mathrm{~h}$ incubation) by immunoblot analysis. (c) The relative ratio of NAD-SDH mRNA to the control by RNA blot analysis. The details are described in Fig. 2. FW = fresh weight.
EFFECT OF VARIOUS SUGARS ON THE EXPRESSION OF NAD-SDH. From the results of sorbitol concentration and the incubation time, we decided to incubate for $24 \mathrm{~h}$ in $100 \mathrm{~mm}$ sugar after $16 \mathrm{~h}$ preincubation in sugar-free media for subsequent experiments. The changes in the activity, protein, and mRNA levels of NAD-SDH were examined by adding $100 \mathrm{~mm}$ of sorbitol, glucose, fructose, sucrose, or mannitol and were compared with the control containing PEG at the same osmotic potential as the sugars supplied. The activity was stimulated to 1.3 and 1.5 times the control (with PEG) by adding mannitol and sorbitol, respectively, and was stimulated by $\approx 1.2$ times by the addition of glucose or sucrose, but the activity was not enhanced by the addition of fructose (Fig. 4). The activity in tissues incubated with PEG corresponded to the activity in media without sugar or PEG. Mannitol, sorbitol, and glucose enhanced protein levels $1.8,1.7$, and 1.5 times, respectively, when compared with the control, but sucrose and fructose enhanced the protein levels only slightly as estimated by immunoblot analysis (Fig. 5). Northern blot analysis revealed that the levels of mRNA were enhanced by the addition of each sugar, including fructose. The levels of mRNA increased 2, 1.9, 1.9, 1.7, and 1.4 times the control in the presence of glucose, fructose, sorbitol, sucrose, and mannitol, respectively (Fig. 6).

\section{Discussion}

To study the regulation of gene expression of NAD-SDH by sugar, we must solve the following important problems. 1) Eliminate the influence of sugars released from sliced tissue on the sugar concentration of the incubation media: The concentration of sugars released from sliced tissues into the media must be maintained below $5 \mathrm{~mm}(<10 \%$ of applied sugar concentration in media) to remove the influence of sugars supplied exogenously.

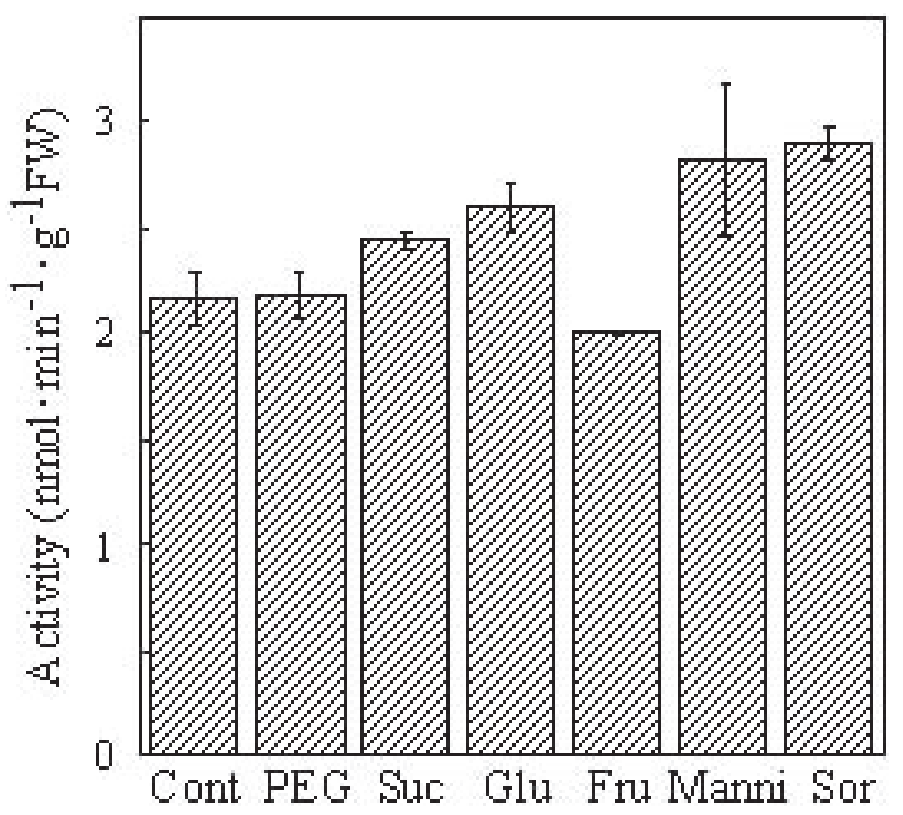

Fig. 4. Enhancement of NAD-SDH activity by adding various sugars. Sliced tissues were incubated in medium A without sugar (control) or with $10 \%$ polyethyleneglycol (PEG), $100 \mathrm{~mm}$ sucrose (suc), $100 \mathrm{~mm}$ glucose (glu), 100 mM fructose (fru), $100 \mathrm{~mm}$ mannitol (manni), and $100 \mathrm{~mm}$ sorbtiol (sor) for $24 \mathrm{~h}$ at $25^{\circ} \mathrm{C}$ after $16 \mathrm{~h}$ preincubation. Each value is the mean $\pm \mathrm{SE}$ of three independent experiments. $\mathrm{FW}=$ fresh weight. 

- $-x=-$

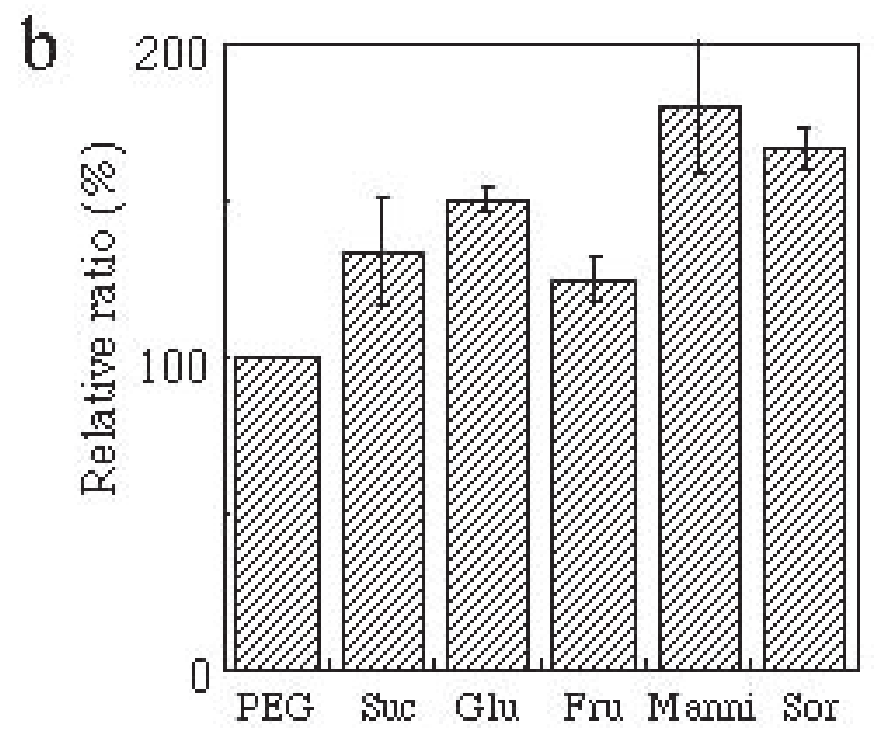

Fig. 5. Enhancement of NAD-SDH protein level by adding various sugars. (a) For immunoblot, soluble protein $(20 \mu \mathrm{g})$ of the same extract as for Fig. 4 was used as described in Fig. 2b. (b) The relative ratio to the control (PEG). Each value in $\mathbf{b}$ is the mean \pm SE of three independent experiments.

In disk tissues of apple (Yamaki and Ino, 1992) and pear (Pyrus communis L. var. sativa DC) (Yamaki et al., 1993) fruits, much sugar is released from the apoplast during the first incubation for several minutes, and is released from cytosol during incubation for $30 \mathrm{~min}$. Thereafter the pools of sugars are gradually released from the vacuole during incubation for a long term. Therefore, the sugar concentration in the apoplast is almost the same as in the incubation media after several minutes. This study showed that the release of sugar after $16 \mathrm{~h}$ preincubation is very slow and the media concentrations remain below 2 mm sugars even after $8 \mathrm{~h}$ incubation. The concentration of released sugars is therefore insignificant when compared to those supplied exogenously in the treatment solutions. 2) The sugar concentration in the cytosol: In previous studies that used disk tissues of apple (Yamaki and Ino, 1992) and pear (Yamaki et al., 1993) fruits, the velocity constants of each sugar across the plasma membrane and tonoplast were measured by using compartment analysis methods. The velocity constant of each sugar across a plasma membrane in immature fruits was $\approx 100$ times higher than across the tonoplast. This means that the plasma membrane is more permeable to each sugar than the tonoplast. In this study, after $16 \mathrm{~h}$ preincubation sugar released from sliced tissues had already reached a steady state. Thus, the sugar concentration in cytosol is expected to be almost equal to that in the apoplast, and that of the concentration in the apoplast. From the results of 1) and 2), we suggest that the sugar concentration in cytosol should be kept below $2 \mathrm{~mm}$ for each $8 \mathrm{~h}$ incubation after $16 \mathrm{~h}$ preincubation in sugar-free media and should be easily equilibrated with the concentration of sugars supplied in the media.

When the supply of photoassimilate for fruit is restricted by girdling stem between leaves and fruit and by defoliation near a PEG Suc Glu Fru Marri Sor

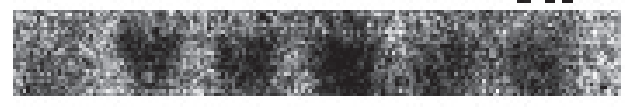

b
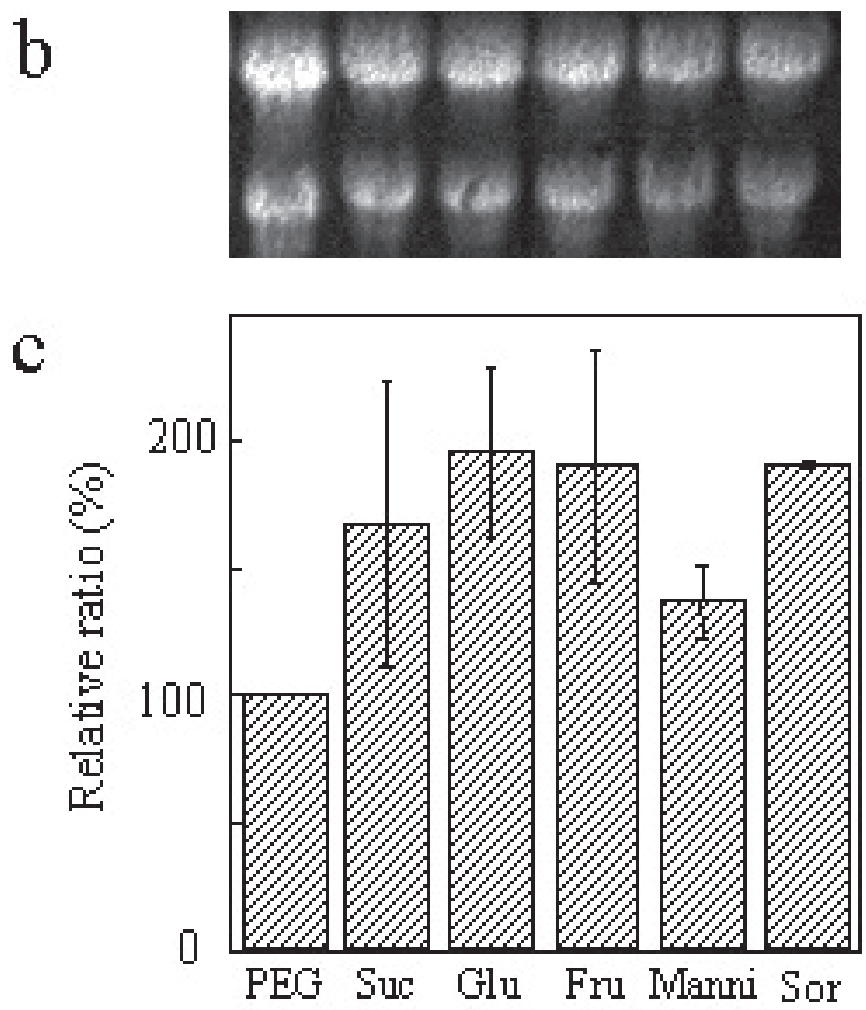

Fig. 6. Enhancement of NAD-SDH mRNA level by adding various sugars. (a) For NAD-SDH mRNA level, total RNA ( $20 \mu \mathrm{g} / \mathrm{lane})$ isolated from sliced tissues incubated in the same conditons as for Fig. 4 was hybridized with the radiolabeled partial NAD-SDH cDNA probe from japanese pear fruit. (b) Ethidium bromide-stain RNA gel. (c) The relative ratio to the control (PEG). Each value is the mean \pm SE of three independent experiments.

the fruit, NAD-SDH activity in fruit is reduced compared to the untreated control. The NAD-SDH activity increases when disk tissues prepared from fruit on girdled trees are incubated in media containing sorbitol (Archbold, 1999). In this study, $50 \mathrm{~mm}$ sorbitol enhanced the NAD-SDH activity, which was accompanied by an increase of NAD-SDH protein and mRNA levels. The enhancement of activity started after $8 \mathrm{~h}$ incubation and continued to increase up to $24 \mathrm{~h}$, but the protein and mRNA levels were maximum after $8 \mathrm{~h}$ incubation. Therefore, the stimulation of NAD-SDH activity by adding sorbitol may be caused by the expression of mRNA.

NAD-SDH activity was stimulated by glucose but not by fructose, as has been described previously for apple fruit tissue (Archbold, 1999). A similar pattern was shown for the protein level. However, the expression of mRNA differed from both the activity and protein level because mRNA levels increased by fructose as well as by glucose. This suggests that lack of stimulation of NAD-SDH activity by fructose is caused by regulating on the translational levels. Sucrose stimulated the NAD-SDH activity and was accompanied by increased protein and mRNA levels. However, as sucrose can be easily converted to glucose and fructose by invertase, whether this stimulation was caused by sucrose itself or by its component of hexoses is unclear. Mannitol also stimulated the activity of NAD-SDH with accompanying 
increases in protein and mRNA levels. As mannitol is usually used as an osmolyte, we investigated if the stimulation was due to changes in the osmotic potential of the media. Therefore, sliced tissues were incubated in media containing PEG at the same osmotic potential; stimulation of the activity, protein, and mRNA of NAD-SDH was not observed and their levels remained similar to the activity level in tissues incubated without PEG or sugars. Thus, we consider the stimulative expression of NAD-SDH at the transcriptional level is due to the sugar itself, and not to an osmotic influence.

The expression of mannitol dehydrogenase (MDH) mRNA in the callus of celery, which mainly uses mannitol as a translocating sugar, is repressed by adding glucose, and is derepressed under starvation conditions that develop once sugars in the media have been consumed during prolonged incubation (Prata et al., 1997). That is, when hexose is readily available, it is predominantly consumed and MDH expression is restricted. Consequently, mannitol accumulates in the tissues to protect them from osmotic stress (Stoop and Pharr, 1996). Further, hexokinase may function as the signal to repress the expression of the MDH gene (Prata et al., 1997). The expression of the NAD-SDH gene in the callus of the peach fruit is induced by hexose depletion (Kanamaru et al., 2002). In this study that used sliced tissues of japanese pear fruit, however, the expression of NAD-SDH mRNA was not repressed by hexose, but was stimulated. NAD-SDH activity was not stimulated by incubation without sugar, although the sugar concentration in the apoplast and cytosol was kept at very low levels that mimicked the starved condition. However, when the influx of loading sugars, including sorbitol, into fruit is restricted by girdling the stem, NAD-SDH activity falls (Berüter and Feusi, 1997) and is stimulated by adding sorbitol to disk tissues prepared from similarly treated fruit (Archbold, 1999). The results of this study of the NAD-SDH activity related to the expression at transcriptional and translational levels support these other studies.

\section{Literature Cited}

Archbold, D.D. 1999. Carbohydrate availability modifies sorbitol dehydrogenase activity of apple fruit. Physiol. Plant. 105:391-395.

Bantog, N.A., K. Yamada, N. Niwa, K. Shiratake, and S. Yamaki. 2000. Gene expression of NAD+-dependent sorbitol dehydrogenase and NADP+-dependent sorbitol-6-phosphate dehydrogenase during development of loquat (Eriobotrya japonica Lindl.) fruit. J. Jpn. Soc. Hort. Sci. 69:231-236.

Bensadoun, A. and D. Weinstein. 1976. Assay of proteins in the presence of interfering materials. Anal. Biochem. 70:241-250.

Berüter, J. and M.E.S. Feusi. 1997 The effect of girdling on carbohydrate partitioning in the growing apple fruit. J. Plant Physiol. 151:277-285.

Claussen, W., J.S. Hawker, and B.R. Loveys. 1986. Influence of sucrose and hormones on the activity of sucrose synthase and invertase in detached leaves and leaf sections of eggplants Solanum melongena. J. Plant Physiol. 124:345-358.

Fu, H., S.Y. Kim, and W.D. Park. 1995. High-level tuber expression and sucrose inducibility of a potato Sus 4 sucrose synthase gene require $5^{\prime}$ and 3' flanking sequences and the leader intron. Plant Cell 7:1387-1394.

Gifford, R.M. and L.T. Evans. 1981. Photosynthesis, carbon partitioning and yield. Annu. Rev. Plant Physiol. 32:485-509.

Godt, D.E., A. Riegel, and T. Roitsch. 1995. Regulation of SS expression in Chenopodium rubrum; characterization of sugar induced expression in photoautorophic suspension cultures and sink tissue specific expression in plants. J. Plant Physiol. 146:231-238.

Hesse, H., U. Sonnewald, and L. Willmitzer. 1995. Cloning and expression analysis of sucrose-phosphate synthase from sugar beet (Beta vulgaris L.). Mol. General Genet. 247:515-520.

Ho, L.C. 1988. Metabolism and compartmentation of imported sugars in sink organs in relation to sink strength. Annu. Rev. Plant Physiol. 39:335-378.
Ichihara, Y. and Y. Kurosawa. 1993. Construction of new T vectors for direct cloning of PCR products. Gene 130:153-154.

Kanamaru, N., Y. Ito, S. Komori, M. Saito, S.Takahashi, J. Soejima, K. Shiratake, and S. Yamaki. 2002. Plant regeneration of sorbitol-6-phosphate dehydrogenase gene-transformed apple and its expression. J. Jpn. Soc. Hort. Sci. 71(Suppl. 2):513.

Koch, K.E. 1996. Carbohydrate-modulated gene expression in plants. Annu. Rev. Plant Physiol. Plant Mol. Biol. 47:509-540.

Koch, K.E., K.D. Nolte, E.R. Duke, D.R. McCarty, and W.T. Avigne. 1992. Sugar levels modulate differential expression of maize SS genes. Plant Cell 4:59-69.

Laemmli, U.K. 1970. Cleavage of structural proteins during the assembly of the head of bacteriophage T4. Nature 227:680-685.

Lee, T.-H., A. Sugiyama, J. Ofosu-Anim, K. Takeno, H. Ohno, and S. Yamaki. 1997. Activation of sucrose-metabolizing enzymes and stimulation of sucrose uptake by auxin and sucrose in eggplant (Solanum melongena L.). J. Plant Physiol. 150:297-301.

Lo Bianco, R., M. Rieger, and S.S. Sung. 1998. A simple, rapid extraction and assay procedure for $\mathrm{NAD}^{+-}$-dependent sorbitol dehydrogenase (SDH) in peach. J. Amer. Soc. Hort. Sci. 123:1065-1068.

Loescher, W.H., G.C. Marlow, and R.A. Kennedy. 1982. Sorbitol metabolism and sink-source interconversions in developing apple. Plant Physiol. 70:335-339.

Murray, M.G. and W.F. Thompson. 1980. Rapid isolation of high molecular weight plant DNA. Nucl. Acids Res. 8:4321-4325.

Nakajima, N., N. Nakagawa, and H. Imaseki. 1988. Molecular size of wound-induced 1-aminocyclopropane-1-carboxylate synthase from Cucurbita maxima Dutch. and change of translatable mRNA of the enzyme after wounding. Plant Cell Physiol. 29:989-998.

Oura, Y., K. Yamada, K. Shiratake, and S. Yamaki. 2000. Purification and characterization of a NAD+-dependent sorbitol dehydrogenase from Japanese pear fruit. Phytochemistry 54:567-572.

Park, S.W., K.J. Song, M.Y. Kim, J.-H. Hwang, Y.U. Shin, W.-C. Kim, and W.-II Chung. 2002. Molecular cloning and characterization of four cDNAs encoding the isoforms of NAD-dependent sorbitol dehydrogenase from the Fuji apple. Plant Sci. 162:513-519.

Prata, R.T.N., J.D. Williamson, M.A. Conkling, and D.M. Pharr. 1997. Sugar repression of mannitol dehydrogenase activity in celery cells. Plant Physiol. 114:307-314.

Roitsch, T., M. Biyner, and D.E. Godt. 1995. Induction of apoplastic invertase of Chenopodium rubrum by D-glucose and a glucose analog and tissue-specific expression suggest a role in sink-source regulation. Plant Physiol. 108:285-294.

Salanoubat, M. and G. Belliard. 1989. The steady-state level of potato sucrose synthase mRNA is dependent on wounding, anaerobiosis, and sucrose concentration. Gene 84:181-185.

Stoop, J.M.H. and D.M. Pharr. 1996. Mannitol metabolism in plants: a method for coping with stress. Trends Plant Sci. 1:139-144.

Towbin, H., T. Staehelin, and J. Gordon. 1979. Electrophoretic transfer of proteins from polyacrylamide gel to nitrocellulose sheets: Procedure and some applications. Proc. Natl. Acad. Sci. USA. 76:4350-4354.

Yamada, K., H. Mori, and S. Yamaki. 1999. Gene expression of NADdependent sorbitol dehydrognease during fruit development of apple (Malus pumila Mill. var. domestica Schneid.). J. Jpn. Soc. Hort. Sci. 68:1099-1103.

Yamada, K., N. Niwa, K. Shiratake, and S. Yamaki. 2001. cDNA cloning of NAD-dependent sorbitol dehydrogenase from peach fruit and its expression during fruit development. J. Hort. Sci. Biotechnol. 76:581-587.

Yamada, K., Y. Oura, H. Mori, and S. Yamaki. 1998. Cloning of NADdependent sorbitol dehydrogenase from apple fruit and gene expression. Plant Cell Physiol. 39:1375-1379.

Yamaki, S. and M. Ino. 1992. Alteration of cellular compartmentation and membrane permeability to sugar in immature and mature apple fruit. J. Amer. Soc. Hort. Sci. 117:951-954.

Yamaki, S., M. Ino, S. Ozaki, Y. Tsuchimoto, and J. Ofosu-Anim. 1993. Cellular compartmentation and transport into tonoplast vesicles of sugars with ripening of pear fruit. Acta Hort. 343:12-17.

Yamaki, S. and K. Ishikawa. 1986. Roles of four sorbitol related enzymes and invertase in the seasonal alteration of sugar metabolism in apple tissue. J. Amer. Soc. Hort. Sci. 111:134-137. 